\title{
ASUPAN ZAT GIZI DAN STATUS GIZI PADA REMAJA PUTRI YANG SUDAH DAN BELUM MENSTRUASI
}

\section{(Nutrient Intake and Nutritional Status of Menstruating and Non-Menstruating Girls)}

Dyan Fajar Christianti ${ }^{1^{*}}$ dan Ali Khomsan ${ }^{1}$

\author{
1Departemen Gizi Masyarakat, Fakultas Ekologi Manusia (FEMA), Institut Pertanian Bogor, Bogor 16680
}

\begin{abstract}
The objective of this study was to analyze nutrient intake and nutritional status of menstruating and nonmenstruating girls. This survey was conducted from April to September 2012 in elementary schools and junior high schools in Bogor. Total subjects consisted of 35 menstruating and 35 non-menstruating girls who were chosen through screening. The results showed that the percentage of menstruating girls in urban (28.0\%) were more than in rural (25.1\%). About $57.1 \%$ of subjects had menarche at 10 years old. The average of nutrient intake on menstruating and non-menstruating girls were under DRI (<90\%). Overweight was more prevalent in menstruating subjects (14.3\%) compared with non-menstruating subjects (2.9\%). Similarly, the percent body fat measurement results showed that overweight and obese subjects were more prevalent in menstruating subjects (17.2\%) compared with non-menstruating subjects (2.9\%). Independent sample $t$-test showed significant differences in age, energy and calcium intake, BMI/age, and percent body fat between menstruating and non-menstruating subjects $(p<0.05)$.
\end{abstract}

Keywords: BMI/age, girls, menstruation, nutrient intake, percent body fat

\begin{abstract}
ABSTRAK
Tujuan penelitian ini adalah untuk menganalisis asupan zat gizi dan status gizi pada remaja putri yang sudah dan belum menstruasi. Survei ini dilaksanakan pada April-September 2012 di Sekolah Dasar (SD) dan Sekolah Menengah Pertama (SMP) di Bogor. Jumlah subjek terdiri dari 35 orang yang sudah menstruasi dan 35 orang yang belum menstruasi dan dipilih melalui screening. Hasil penelitian menunjukkan bahwa persentase terjadinya menstruasi pada siswi di sekolah kota lebih besar (28.0\%) dibandingkan dengan di kabupaten (25.1\%). Sebanyak $57.1 \%$ subjek mengalami menarche pada usia 10 tahun. Rata-rata asupan zat gizi subjek yang sudah dan belum menstruasi masih berada di bawah AKG $(<90 \%)$. Status gizi overweight lebih banyak ditemukan pada subjek yang sudah menstruasi (14.3\%) dibandingkan dengan subjek yang belum menstruasi (2.9\%). Demikian pula dengan hasil pengukuran persen lemak tubuh yang menunjukkan bahwa kategori lemak tubuh overweight dan obesitas lebih banyak ditemukan pada subjek yang sudah menstruasi (17.2\%) dibandingkan dengan subjek yang belum menstruasi (2.9\%). Hasil independent sample $t$-test menunjukkan adanya perbedaan yang signifikan pada usia, asupan energi, dan kalsium, IMT/U, serta persen lemak tubuh antara subjek yang sudah dan belum menstruasi $(p<0.05)$.
\end{abstract}

Kata kunci: asupan zat gizi, IMT/U, menstruasi, persen lemak tubuh, remaja putri

"Korespondensi: Departemen Gizi Masyarakat, Fakultas Ekologi Manusia (FEMA), Institut Pertanian Bogor, Bogor 16680. Email: dyanfajar38@gmail.com 


\section{PENDAHULUAN}

Remaja merupakan periode perubahan fisiologis, psikologis, dan kognitif yang terjadi pada masa anak-anak menjadi dewasa muda. Masa remaja disebut juga dengan masa pubertas, artinya masa ketika anak mulai mengalami kematangan secara seksual dan organ reproduksi siap untuk menjalankan fungsinya. Masa pubertas remaja putri umumnya terjadi pada usia 8-13 tahun. Terjadinya pubertas merupakan akibat peningkatan sekresi GnRH dari hipotalamus yang memberikan sinyal pada kelenjar pituitari untuk melepaskan LH dan FSH untuk memulai perkembangan seksual (Batubara 2010).

Ciri pubertas yang sangat penting pada remaja putri adalah mulai mengalami menstruasi pertama yang disebut menarche. Menstruasi merupakan peristiwa perdarahan uterus yang terjadi secara siklik dan dialami oleh sebagian besar wanita usia produktif. Rata-rata usia menarche remaja putri di Indonesia adalah 13 tahun. Data Riskesdas (2010) menunjukkan bahwa remaja putri yang telah mengalami menarche pada usia 9-10 tahun sebanyak $1.7 \%, 11-12$ tahun $20.3 \%$, dan $13-14$ tahun $38.1 \%$.

Terjadinya menarche dipengaruhi oleh berbagai macam faktor. Hasil penelitian Cho et al. (2010) dengan metode kohort menunjukkan bahwa usia menarche perempuan yang lahir antara tahun 19861995 dipengaruhi oleh lingkar pinggang, Indeks Massa Tubuh (IMT) yang tinggi, usia menarche ibu (genetik), serta asupan gizi. Demikian pula dengan hasil penelitian Lusiana (2008) yang menunjukkan adanya hubungan nyata negatif antara usia menarche dengan status gizi. Penelitian yang dilakukan oleh Abdulla dan Ibraheem (2010) menunjukkan bahwa usia menarche memiliki hubungan yang signifikan dengan IMT, stres, dan aktivitas fisik. Simpanan lemak dalam jaringan adiposa berkorelasi positif dengan peningkatan kadar leptin yang memicu pengeluaran GnRH dan mempercepat waktu pubertas (Quennell et al. 2009).

Secara umum, status gizi memberikan pengaruh yang signifikan terhadap terjadinya menstru- asi. Diduga terdapat adanya perbedaan status gizi antara remaja yang sudah dan belum menstruasi. Penelitian ini bertujuan untuk menganalisis asupan zat gizi dan status gizi pada remaja putri yang sudah dan belum menstruasi.

\section{METODE}

\section{Desain, Tempat, dan Waktu}

Penelitian ini merupakan penelitian survei yang dilakukan pada bulan April-September 2012 di tiga sekolah terpilih di Kabupaten Bogor, yaitu SD Negeri Babakan 01 Dramaga, SD Negeri Babakan 03 Dramaga, SMP Negeri 1 Dramaga serta dua sekolah terpilih di Kota Bogor, yaitu SD Bina Insani dan SMP Bina Insani. Pemilihan sekolah dilakukan secara purposive dengan mempertimbangkan lokasi sekolah serta keadaan ekonomi yang bervariasi.

\section{Jumlah dan Cara Penarikan Subjek}

Populasi pada penelitian ini adalah siswi kelas 6 SD Negeri Babakan 01 Dramaga, SD Negeri Babakan 03 Dramaga, dan SD Bina Insani serta siswi kelas 7 SMP Negeri 1 Dramaga dan SMP Bina Insani. Tabel 1 menunjukkan jumlah subjek penelitian (n) pada masing-masing sekolah dengan total sebanyak 70 orang yang terbagi menjadi 35 subjek yang sudah menstruasi dan 35 subjek yang belum menstruasi. Seluruh siswi kelas 6 yang sudah menstruasi (23 orang) dijadikan sebagai subjek dalam penelitian ini, sedangkan untuk siswi kelas 7 dipilih salah satu kelas dengan jumlah siswi terbanyak yang sudah menstruasi untuk memenuhi jumlah subjek yang diharapkan (35 orang).

Penarikan subjek dilakukan dengan melakukan screening awal melalui wawancara kepada seluruh siswi kelas 6 dan 7 pada kelima sekolah tersebut. Pertimbangan pengambilan subjek kelas 6 dan 7 didasarkan pada usia menstruasi pertama (menarche) yang kini banyak terjadi pada usia remaja awal (10-12 tahun). Subjek yang sudah menstruasi dipilih menggunakan kriteria inklusi, yaitu 1) telah mengalami menstruasi pada screening awal; 2)

Tabel 1. Jumlah Subjek Penelitian pada Masing-masing Sekolah

\begin{tabular}{lcccc}
\hline \multirow{2}{*}{ Nama Sekolah } & \multicolumn{2}{c}{ Sudah Menstruasi } & \multicolumn{2}{c}{ Belum Menstruasi } \\
\cline { 2 - 5 } & $\mathrm{N}$ & $\mathrm{n}$ & $\mathrm{N}$ & $\mathrm{n}$ \\
\hline Kabupaten Bogor: & 7 & 7 & 36 & 7 \\
-SDN Babakan 01 Dramaga & 2 & 2 & 40 & 2 \\
-SDN Babakan 03 Dramaga & 60 & 8 & 130 & 8 \\
-SMPN 1 Dramaga & & & & \\
Kota Bogor: & 14 & 14 & 61 & 14 \\
-SD Bina Insani & 28 & 4 & 47 & 4 \\
-SMP Bina Insani & 111 & 35 & 314 & 35 \\
Total & & & & \\
\hline
\end{tabular}


berusia 10-12 tahun; 3) bersedia diwawancara dan memberikan keterangan yang lengkap, jelas, serta benar.

Subjek dalam penelitian ini juga terdiri atas siswi yang belum menstruasi dengan teknik penarikan subjek simple random sampling sebanyak jumlah subjek yang sudah menstruasi pada masingmasing sekolah. Kriteria inklusi untuk subjek yang belum menstruasi, yaitu 1) belum mengalami menstruasi; 2) berusia 10-12 tahun; dan 3) bersedia diwawancara dan memberikan keterangan yang lengkap, jelas, serta benar.

\section{Jenis dan Cara Pengumpulan Data}

Jenis data yang dikumpulkan meliputi keadaan ekonomi keluarga, usia, asupan zat gizi, status gizi (IMT/U dan persen lemak tubuh), aktivitas fisik, dan menstruasi (usia menarche subjek dan ibu, frekuensi, lama, siklus, keteraturan, serta keluhan menstruasi). Pengambilan data dilakukan melalui metode wawancara menggunakan kuesioner kepada subjek dan orang tua subjek. Selain itu, dilakukan pula pengukuran tinggi badan dengan microtoise serta berat badan dan persen lemak tubuh dengan timbangan digital body fat scale kepada subjek.

\section{Pengolahan dan Analisis Data}

Uji statistik yang digunakan adalah independent sample t-test untuk mengetahui perbedaan keadaan ekonomi keluarga, usia, asupan zat gizi (energi, protein, lemak, kalsium), status gizi (IMT/U dan persen lemak tubuh), aktivitas fisik, dan usia menarche ibu subjek. Selanjutnya uji chi-square digunakan untuk mengetahui perbedaan jumlah siswi yang sudah menstruasi berdasarkan lokasi sekolah dan kebiasaan olahraga.

\section{HASIL DAN PEMBAHASAN}

\section{Jumlah Siswi Menstruasi}

Tabel 2 menunjukkan bahwa jumlah siswi yang sudah menstruasi di sekolah yang berada di Kota Bo- gor lebih banyak $(28.0 \%)$ dibandingkan dengan siswi di Kabupaten Bogor (25.1\%). Hal ini sejalan dengan hasil penelitian Ikaraoha et al. (2005) dan Paçadara et al. (2008) yang menyatakan bahwa usia menarche remaja putri di kota lebih muda dibandingkan dengan remaja putri di desa. Hal tersebut berkaitan dengan keadaan ekonomi keluarga dan gaya hidup. Semakin baik keadaan ekonomi keluarga akan berpengaruh terhadap kemudahan dalam memperoleh makanan yang berkualitas sehingga status gizi juga akan semakin baik. Hasil uji chi-square tidak menunjukkan adanya perbedaan jumlah siswi yang sudah menstruasi berdasarkan lokasi sekolah di kabupaten maupun kota $(p>0.05)$.

\section{Keadaan Ekonomi Keluarga}

Menurut BPS Jawa Barat (2012), keluarga dengan pendapatan/kap/bulan <Rp 231438 dikategorikan sebagai keluarga miskin. Rata-rata pendapatan/kap/bulan keluarga subjek yang sudah menstruasi adalah Rp 1367 157 \pm 1213680 dan subjek yang belum menstruasi Rp $1220272 \pm 1045948$. Keluarga tidak miskin dengan pendapatan $\geq$ Rp 231 438/kap/bulan ditemukan pada $88.6 \%$ subjek yang sudah menstruasi dan $82.9 \%$ pada subjek yang belum menstruasi.

Ikaraoha et al. (2005) dan Paçadara et al. (2008) menyatakan bahwa remaja putri dengan status sosial ekonomi menengah dan tinggi mengalami menarche lebih cepat dibandingkan dengan remaja putri dengan status sosial ekonomi rendah. Hal ini berkaitan dengan kemudahan untuk mendapatkan makanan berkualitas yang berpengaruh pada status gizi. Hasil independent sample t-test menunjukkan tidak adanya perbedaan pendapatan/kap/bulan keluarga pada kedua kelompok subjek $(p>0.05)$ karena dalam penelitian ini hampir seluruh keluarga subjek termasuk dalam kategori tidak miskin.

\section{Usia}

Subjek berusia 11 tahun pada kelompok yang sudah menstruasi berjumlah $68.6 \%$ dan pada kelom-

Tabel 2. Persentase Menstruasi Remaja Putri menurut Lokasi Sekolah

\begin{tabular}{lccccccc}
\hline \multirow{2}{*}{ Nama Sekolah } & \multicolumn{2}{c}{ Sudah Menstruasi } & \multicolumn{2}{c}{ Belum Menstruasi } & \multicolumn{2}{c}{ Total } & \multirow{2}{*}{$\begin{array}{c}\text { Nilai } \mathbf{p} \\
\text { (uji beda) }\end{array}$} \\
\cline { 2 - 6 } & $\mathrm{n}$ & $\%$ & $\mathrm{n}$ & $\%$ & $\mathrm{n}$ & $\%$ & \\
\hline Kabupaten Bogor: & & & & & & & \\
-SDN Babakan 01 Dramaga & 7 & 16.3 & 36 & 83.7 & 43 & 100.0 & \\
-SDN Babakan 03 Dramaga & 2 & 4.8 & 40 & 95.2 & 42 & 100.0 & \\
-SMPN 1 Dramaga & 60 & 31.6 & 130 & 68.4 & 190 & 100.0 & \\
Total & 69 & 25.1 & 206 & 74.9 & 275 & 100.0 & 0.514 \\
Kota Bogor: & & & & & & & \\
-SD Bina Insani & 14 & 18.7 & 61 & 81.3 & 75 & 100.0 & \\
-SMP Bina Insani & 28 & 37.3 & 47 & 62.7 & 75 & 100.0 & \\
Total & 42 & 28.0 & 108 & 72.0 & 150 & 100.0 & \\
\hline
\end{tabular}


Tabel 3. Sebaran Subjek menurut Usia

\begin{tabular}{ccccc}
\hline \multirow{2}{*}{ Usia (Tahun) } & \multicolumn{2}{c}{ Sudah Menstruasi } & \multicolumn{2}{c}{ Belum Menstruasi } \\
\cline { 2 - 5 } & $\mathrm{n}=35$ & $\%$ & $\mathrm{n}=35$ & $\%$ \\
\hline 10 & 3 & 8.6 & 11 & 31.4 \\
11 & 24 & 68.6 & 21 & 60.0 \\
12 & 8 & 22.9 & 3 & 8.6 \\
Rata-rata \pm SD & \multicolumn{2}{c}{$11.14 \pm 0.55$} & $10.77 \pm 0.60$ \\
\hline
\end{tabular}

Tabel 4. Asupan Zat Gizi, Angka Kecukupan Gizi, dan Tingkat Kecukupan Gizi Subjek

\begin{tabular}{lccc}
\hline \multicolumn{1}{c}{ Zat Gizi } & Sudah Menstruasi & Belum Menstruasi & Nilai p (uji beda) \\
\hline Energi: & 1146 & 1324 & \\
-Asupan gizi (kkal) & 2300 & 2055 & 0.002 \\
-Kecukupan (kkal) & 50.0 & 65.9 & \\
-Tingkat kecukupan (\%) & & & \\
Protein: & 39.0 & 35.3 & 0.781 \\
-Asupan gizi (g) & 57.7 & 51.0 & \\
-Kecukupan (g) & 67.4 & 70.3 & \\
-Tingkat kecukupan (\%) & & & \\
Lemak: & 43.7 & 44.1 & \\
-Asupan gizi (g) & 63.9 & 57.0 & \\
-Kecukupan (g) & 69.0 & 78.8 & \\
-Tingkat kecukupan (\%) & & & \\
Kalsium: & 931.9 & 2457.5 & \\
-Asupan gizi (mg) & 1000.0 & 1000.0 & \\
-Kecukupan (mg) & 93.2 & 245.8 & \\
-Tingkat kecukupan (\%) & & & \\
\hline
\end{tabular}

pok yang belum menstruasi 60.0\% (Tabel 3). Rata-rata usia kelompok subjek yang sudah menstruasi lebih tua $(11.14 \pm 0.55$ tahun) dibandingkan dengan kelompok subjek yang belum menstruasi $(10.77 \pm 0.60$ tahun). Hasil independent sample t-test menunjukkan adanya perbedaan usia yang signifikan pada kedua kelompok subjek $(p<0.05)$.

\section{Asupan Zat Gizi}

Asupan atau konsumsi pangan yang berlebihan akan disimpan dalam tubuh (jaringan adiposa) yang berkorelasi positif dengan peningkatan kadar leptin sehingga memicu pengeluaran GnRH dan mempercepat waktu pubertas (Lee 2007; Quennell et al. 2009). Lassek dan Gaulin (2007) menyatakan bahwa level hormon leptin berhubungan terbalik dengan masa pubertas dan usia menarche. Leptin dihasilkan oleh jaringan lemak untuk mengatur kebiasaan makan serta berperan dalam mengatur masa awal pubertas (Batubara 2010).

Tabel 4 menunjukkan bahwa rata-rata tingkat kecukupan energi, protein, lemak, dan kalsium subjek yang sudah menstruasi lebih rendah dibandingkan dengan subjek yang belum menstruasi. Hal ini diduga oleh adanya persepsi mengenai body image yang terjadi pada usia remaja awal. Remaja putri lebih memperhatikan dan merasa kurang puas dengan keadaan tubuhnya serta memiliki citra negatif akibat penambahan lemak tubuh pada masa tersebut (Santrock 2003). Hasil penelitian menunjukkan adanya perbedaan tingkat kecukupan energi dan kalsium $(p<0.05)$ pada kedua kelompok subjek, akan tetapi tingkat kecukupan protein dan lemak pada subjek yang sudah menstruasi dan subjek yang belum menstruasi tidak menunjukkan adanya perbedaan ( $p>0.05)$. Susanti dan Sunarto (2012) menyatakan bahwa faktor risiko terjadinya menarche dini adalah rendahnya asupan serat dan tingginya asupan lemak serta kalsium.

\section{Status Gizi}

Penelitian Labayen et al. (2009) menunjukkan bahwa kematangan seksual yang lebih awal dihubungkan dengan meningkatnya IMT dan lemak tubuh. Tabel 5 menunjukkan bahwa berdasarkan pengukuran IMT/U, status gizi overweight lebih banyak ditemukan pada kelompok yang sudah menstruasi (14.3\%) dibandingkan dengan subjek yang belum menstruasi (2.9\%). Sebaliknya, status gizi kurus hanya ditemukan pada kelompok subjek yang be- 
Tabel 5. Sebaran Subjek menurut Status Gizi

\begin{tabular}{|c|c|c|c|c|}
\hline \multirow{2}{*}{ Status Gizi } & \multicolumn{2}{|c|}{ Sudah Menstruasi } & \multicolumn{2}{|c|}{ Belum Menstruasi } \\
\hline & $n=35$ & $\%$ & $n=35$ & $\%$ \\
\hline \multicolumn{5}{|l|}{ IMT/U: } \\
\hline -Sangat kurus & 0 & 0.0 & 0 & 0.0 \\
\hline -Kurus & 0 & 0.0 & 3 & 8.6 \\
\hline -Normal & 30 & 85.7 & 31 & 88.6 \\
\hline -Overweight & 5 & 14.3 & 1 & 2.9 \\
\hline -Obesitas & 0 & 0.0 & 0 & 0.0 \\
\hline Rata-rata $\pm S D$ & \multicolumn{2}{|c|}{$0.6 \pm 1.0$} & \multicolumn{2}{|c|}{$-0.2 \pm 1.4$} \\
\hline \multicolumn{5}{|c|}{ Persen Lemak tubuh: } \\
\hline -Kurang & 2 & 5.7 & 12 & 34.3 \\
\hline -Normal & 24 & 68.6 & 19 & 54.3 \\
\hline -Risiko rendah & 3 & 8.6 & 3 & 8.6 \\
\hline -Overweight & 5 & 14.3 & 0 & 0.0 \\
\hline -Obesitas & 1 & 2.9 & 1 & 2.9 \\
\hline Rata-rata $\pm S D$ & \multicolumn{2}{|c|}{$20.3 \pm 5.8$} & \multicolumn{2}{|c|}{$16.0 \pm 5.9$} \\
\hline
\end{tabular}

lum menstruasi (8.6\%). Sunarto dan Mayasari (2010) menyatakan bahwa kelebihan berat badan memiliki hubungan dengan menarche dini. Demikian pula dengan hasil penelitian Cho et al. (2010), remaja putri yang sudah menstruasi memiliki nilai IMT yang lebih tinggi dibandingkan dengan remaja putri yang belum menstruasi. Wang et al. (2006) juga mengungkapkan bahwa massa lemak dan IMT memiliki hubungan signifikan negatif dengan usia menarche.

Hasil penelitian menunjukkan adanya perbedaan status gizi pada subjek yang sudah menstruasi dan yang belum menstruasi $(p<0.05)$. Hasil pengukuran persen lemak tubuh menunjukkan bahwa subjek dengan lemak tubuh kategori overweight dan obesitas lebih banyak ditemukan pada kelompok subjek yang sudah menstruasi (17.2\%) dibandingkan dengan kelompok subjek yang belum menstruasi (2.9\%). Hal ini sesuai dengan hasil penelitian Lassek dan Gaulin (2007) yang menyatakan bahwa usia menarche berhubungan dengan tingginya proporsi lemak tubuh. Semakin tinggi persen lemak tubuh maka produksi leptin akan semakin meningkat sehingga berpengaruh terhadap masa pubertas remaja. Hal ini disebabkan oleh produksi leptin yang berasal dari sel lemak serta peran leptin dalam mengatur kebiasaan makan dan masa pubertas (Batubara 2010). Hasil penelitian menunjukkan adanya perbedaan persen lemak tubuh pada kedua kelompok subjek tersebut $(p<0.05)$.

\section{Aktivitas Fisik}

Tabel 6 menunjukkan frekuensi aktivitas fisik $<3 \mathrm{kali} /$ minggu dilakukan oleh $82.9 \%$ subjek yang sudah menstruasi dan $82.9 \%$ subjek yang belum menstruasi. Hasil uji chi-square menunjukkan tidak adanya perbedaan frekuensi aktivitas fisik pada ke- dua kelompok subjek ( $p>0.05$ ). Durasi aktivitas fisik 15-30 menit dilakukan oleh $68.6 \%$ subjek yang sudah menstruasi dan $54.3 \%$ subjek yang belum menstruasi. Hasil penelitian menunjukkan tidak adanya perbedaan durasi aktivitas fisik pada kedua kelompok subjek ( $p>0.05)$.

Abdulla dan Ibraheem (2010) menyatakan bahwa usia menarche memiliki hubungan yang signifikan dengan Indeks Massa Tubuh (IMT), stres, dan aktivitas fisik. Menurut Sherar (2007), usia menarche yang terlambat umumnya terjadi pada atlet putri karena rendahnya lemak dan atau massa tubuh. Akan tetapi, hasil penelitian ini tidak sejalan dengan penelitian sebelumnya. Hal ini diduga disebabkan karena bentuk aktivitas fisik yang dilakukan oleh subjek yang sudah menstruasi tidak tergolong olahraga berat. Selain itu, frekuensi aktivitas fisik antara kedua kelompok subjek tersebut relatif sama.

\section{Menstruasi}

Tabel 7 menunjukkan bahwa sebanyak $57.1 \%$ subjek mengalami menarche pada usia 10 tahun dengan rata-rata $10.0 \pm 0.6$ tahun. Menurut data Riskesdas (2010), rata-rata usia menarche remaja putri di Indonesia adalah 13 tahun. Hal tersebut menunjukkan bahwa terjadi penurunan usia menarche yang diduga disebabkan oleh keadaan gizi dan kesehatan umum yang semakin baik (Lusiana 2008).

Tehrani et al. (2010) yang menyatakan bahwa usia menarche ibu dan anak memiliki korelasi positif. Semakin muda usia menarche ibu maka semakin muda pula usia menarche anak. Adanya hubungan ini diduga berkaitan dengan lokus pengatur estrogen yang diwariskan (Mitchell 2008). Rata-rata usia menarche ibu subjek yang sudah menstruasi 
Tabel 6. Sebaran Subjek menurut Aktivitas Fisik

\begin{tabular}{lcccc}
\hline \multirow{2}{*}{ Variabel } & \multicolumn{2}{c}{ Sudah Menstruasi } & \multicolumn{2}{c}{ Belum Menstruasi } \\
\cline { 2 - 5 } & $\mathrm{n}=35$ & $\%$ & $\mathrm{n}=35$ & $\%$ \\
\hline $\begin{array}{l}\text { Frekuensi (kali/minggu): } \\
\quad 3\end{array}$ & 29 & 82.9 & 29 & 82.9 \\
$\quad 3$ & 6 & 17.1 & 6 & 17.1 \\
Rata-rata \pm SD & & $1.7 \pm 0.8$ & & $1.7 \pm 1.0$ \\
Durasi (menit): & & & & \\
$<15$ & 3 & 8.6 & 3 & 8.6 \\
$15-30$ & 24 & 68.6 & 19 & 54.3 \\
$31-60$ & 6 & 17.1 & 9 & 25.7 \\
$>60$ & 2 & 5.7 & 4 & 11.4 \\
Rata-rata \pm SD & \multicolumn{2}{c}{$35.7 \pm 26.3$} & \multicolumn{2}{c}{$41.9 \pm 29.3$} \\
\hline
\end{tabular}

Tabel 7. Sebaran Subjek menurut Usia Menarche

\begin{tabular}{ccc}
\hline Usia (Tahun) & $\mathrm{n}=\mathbf{3 5}$ & $\%$ \\
\hline 9 & 2 & 5.7 \\
10 & 20 & 57.1 \\
11 & 12 & 34.3 \\
12 & 1 & 2.9 \\
Rata-rata \pm SD & & $10.0 \pm 0.6$ \\
\hline
\end{tabular}

Tabel 8. Sebaran Subjek menurut Indikator yang Berkaitan dengan Menstruasi

\begin{tabular}{lcc}
\hline \multicolumn{1}{c}{ Variabel } & $\mathrm{n}=35$ & $\%$ \\
\hline Frekuensi Menstruasi hingga Sekarang: & & \\
$\quad$ <5 kali & 19 & 54.3 \\
$5-10$ kali & 10 & 28.6 \\
$>10$ kali & 6 & 17.1 \\
Lama Menstruasi: & & \\
<3 hari & 2 & 5.7 \\
4-8 hari & 30 & 85.7 \\
9-15 hari & 3 & 8.6 \\
$>15$ hari & 0 & 0.0 \\
Siklus Menstruasi: & & \\
$<20$ hari & 4 & 11.4 \\
20-35 hari & 14 & 40.0 \\
$>35$ hari & 17 & 48.6 \\
Keteraturan Menstruasi: & & \\
Teratur & 13 & 37.1 \\
Tidak teratur & 22 & 62.9 \\
Keluhan Menstruasi: & & \\
Ya & 30 & 85.7 \\
Tidak & 5 & 14.3 \\
\hline
\end{tabular}

lebih muda $(12.9 \pm 1.2$ tahun) dibandingkan dengan ibu subjek yang belum menstruasi (13.0 \pm 1.2 tahun). Hasil independent sample $t$-test menunjukkan tidak adanya perbedaan usia menarche ibu $(p>0.05)$ pada kedua kelompok subjek.
Tabel 8 menunjukkan bahwa subjek yang mengalami menstruasi $<5$ kali hingga saat wawancara berjumlah $54.3 \%$ dan sebanyak $14.3 \%$ subjek baru mengalami menarche. Lama menstruasi 4-8 hari dialami oleh $85.7 \%$ subjek. Sebanyak $48.6 \%$ 
subjek mengalami siklus menstruasi $>35$ hari. Menstruasi yang tidak teratur dialami oleh $62.9 \%$ subjek. Siklus menstruasi yang panjang atau tidak teratur pada subjek terutama yang baru mengalami menarche merupakan mekanisme untuk memberikan kesempatan yang cukup agar tanda-tanda seks sekunder berkembang dengan baik. Tanda-tanda seks sekunder tersebut meliputi pertumbuhan rambut ketiak, rambut pubis (kemaluan), pertumbuhan dan perkembangan buah dada, serta pertumbuhan dan distribusi jaringan lemak terutama pada bagian pinggul (Manuaba et al. 2007).

Tabel 8 juga menunjukkan bahwa sebagian besar subjek (85.7\%) dan ibu subjek (80.0\%) mengalami keluhan selama menstruasi. Keluhan yang sering dirasakan oleh subjek adalah timbul jerawat $(23.3 \%)$ dan kram perut (23.3\%). Berbeda halnya dengan ibu subjek, yang mengalami keluhan perut kembung $(21.4 \%)$ dan mudah marah $(21.4 \%)$. Hasil penelitian ini mendukung pernyataan Lusiana (2008), yaitu $90.0 \%$ anak perempuan sekolah dasar mengalami keluhan menstruasi dan $55.6 \%$ mengeluh sakit/kram pada perut bagian bawah yang disebabkan oleh kejang otot uterus. Upaya yang dilakukan oleh sebagian subjek (56.7\%) untuk mengatasi keluhan menstruasi adalah istirahat/tidur.

\section{KESIMPULAN}

Hasil penelitian menunjukkan bahwa terdapat perbedaan yang signifikan pada usia, asupan energi dan kalsium, status gizi (IMT/U), dan persen lemak tubuh antara subjek yang sudah dan belum menstruasi. Akan tetapi, tidak ditemukan adanya perbedaan keadaan ekonomi keluarga, aktivitas fisik, dan usia menarche ibu pada kedua kelompok subjek. Penelitian serupa disarankan menggunakan metode kohort untuk mengetahui adanya pengaruh kesehatan masa lampau sebelum menstruasi dengan usia menarche atau membandingkan antara status gizi remaja sebelum dan setelah menstruasi.

\section{DAFTAR PUSTAKA}

Abdulla E \& Ibraheem NM. 2010. Assessment of the influencing factors on age of menarche among girls in Tikrit city. Tikrit Medical Journal, 16(2), 129-133.

Batubara JRL. 2010. Adolescent development (perkembangan remaja). Sari Pediatri, 12 (1).

[BPS] Badan Pusat Statistik Jawa Barat. 2012. Tingkat kemiskinan Jawa Barat Maret http:// jabar.bps.go.id [11 Nov 2012].

Cho JG et al. 2010. Age at menarche in a Korean population: secular trends and influencing factors. European Journal Pediatrics, 169, 89-94.

[Depkes] Departemen Kesehatan RI. 2010. Laporan Riset Kesehatan Dasar [Riskesdas] 2010. Badan Penelitian dan Pengembangan Kesehatan, Kementrian Kesehatan RI, Jakarta.

Ikaraoha $\mathrm{Cl}$ et al. 2005. Menarchial age of secondary school girls in urban and rural areas of rivers state, Nigeria. Online Journal of Health and Allied Sciences, 2(4).

Labayen I et al. 2009. The effect of early menarche on later body composition and fat distribution in female adolescents: role of birth weight. Annals of Nutrition and Metabolism, 54, 313320.

Lassek WD \& Gaulin SJC. 2007. Menarche is related to fat distribution. American Journal of Physical Anthropology 000:000-000.

Lee JM, Appugliese D, Kaciroti N, Corwyn RF, \& Robert H. 2007. Weight status in young girls and the onset of puberty. Pediatrics, 119(3).

Lusiana SA \& Dwiriani CM. 2008. Usia menarche, konsumsi pangan, dan status gizi anak perempuan sekolah dasar di Bogor. Jurnal Gizi dan Pangan, 2(3), 26-35.

Manuaba IBG, Manuaba IAC, \& Manuaba IBGF. 2007. Pengantar Kuliah Obstetri. EGC, Jakarta.

Mitchell ES et al. 2008. Association of estrogen-related polymorphisms with age at menarche, age at final menstrual period, and stages of the menopausal transition. PubMed, 15(1), 105-111.

Paçadara M, Lulaj S, Kongjeli G, \& Obërtinca B. 2008. Impact of socio-economic factors on the onset of menarche in Kosovar girls. Journal of Chinese Clinical Medicine, 3(10), 541-549.

Quennell JH et al. 2009. Leptin indirecty regulates gonadotropin-releasing hormone neurona function. Epub, 150(6), 2805-2812.

Santrock. 2003. Perkembangan Remaja. Edisi Ke-6. Adelar SB, Saragih S, penerjemah. Terjemahan dari: Adolescence. Erlangga, Jakarta.

Sherar LB, Jones ADGB, \& Mirwald Rl. 2007. The relationship between body composition and onset of menarche. Annals of Human Biology 34(6), 673-677.

Sunarto \& Mayasari ID. 2010. Hubungan kelebihan berat badan dengan menarche dini. Jurnal Penelitian Kesehatan Suara Forikes, 1(4), 265-272.

Susanti AV \& Sunarto. 2012. Faktor risiko kejadian menarche dini pada remaja di SMPN $30 \mathrm{Se}$ marang. Journal of Nutrition College, 1(1), 386-407.

Tehrani FR, Mirmiran P, Zahedi-Asl S, Nakhoda K, \& Azizi F. 2010. Menarcheal age of mothers 
Christianti \& Khomsan

and daughters: Tehran lipid and glucose study. Eastern Mediterranean Health Journal, 16(4), 391-395.

Wang W, Zhao LJ, Liu YZ, Recker RR, \& Deng HW.
2006. Genetic and environmental correlation between obesity phenotypes and age at menarche. International Journal of Obesity, 30, 1595-1600. 